\title{
ANALISIS IMPLEMENTASI ISO 9001:2015 KLAUSUL OPERASI PADA DIREKTORAT PELATIHAN KOMPETENSI LEMBAGA KEBIJAKAN PENGADAAN BARANG/JASA PEMERINTAH TAHUN 2017
}

\author{
Indah Mutiara Garini \\ Moch. Rum Alim \\ Email: indahmutiaragarini@gmail.com \\ Program Studi Manajemen Fakultas Ekonomi \\ Universitas Nasional
}

\begin{abstract}
ABSTRAK
Penelitian ini bertujuan untuk menganalisis implementasi ISO 9001:2015 klausul operasi pada unit kerja Direktorat Pelatihan Kompetensi Lembaga Kebijakan Pengadaan Barang/Jasa Pemerintah (LKPP), menganalisis permasalahan yang dihadapi dalam implementasinya dan mengidentifikasi langkah pemecahan atas permasalahan tersebut. Penelitian ini menggunakan data primer dan data sekunder yang diolah dengan menggunakan Fishbone Diagram dan metode Analytical Hierarchy Process (AHP). Hasil penelitian menunjukkan bahwa elemenelemen yang memiliki prioritas di setiap level hierarki secara berturut-turut adalah komunikasi pelanggan, top management, peningkatan kompetensi Pengadaan Barang dan Jasa (PBJ), serta pendidikan dan pelatihan (diklat). Upaya untuk memenuhi kesesuaian dari setiap persyaratan yang terdapat dalam subklausul komunikasi pelanggan, penentuan persyaratan produk dan jasa, perubahan persyaratan pada produk dan jasa, serta preservasi telah dilakukan dengan baik oleh Direktorat tersebut sejak tahun 2015, tetapi implementasinya masih belum optimal karena masih terjadi beberapa permasalahan. Alternatif tindakan yang dapat dilakukan untuk mengatasi masalah yang timbul tersebut yaitu meningkatkan pelaksanaan diklat untuk meningkatkan kompetensi dan produktivitas pegawai.
\end{abstract}

Kata kunci: ISO 9001:2015, komunikasi pelanggan, penentuan persyaratan produk dan jasa, perubahan persyaratan produk dan jasa, preservasi

\section{ABSTRACT}

This research aims to analyze the implementation of ISO 9001:2015 operation clause in Directorate of Competency Training of the National Public Procurement Agency, analyze the problems faced in its implementation and identify steps to solve the problems. This research used primary and secondary data that processed by Fishbone Diagram and Analytical Hierarchy Process (AHP) method. The result of this research showed that priority elements in each hierarchy level in a row were customer focus, top management, improvement of competence of the goods and services procurement, and education and training. The effort to fulfill every requirement in subclause customer communication, determination of the requirements for products and services, changes on requirements for products and services, as well as preservation has been done well by the Directorate since 2015, but the implementation is still not optimal because there are still some problems. Alternative actions that can be done to overcome the problems that arise is increasing the implementation of education and training to improve employee competency and productivity.

Keywords: ISO 9001:2015, customer communication, determination of the requirements for products and services, changes on requirements for products and services, preservation 


\section{PENDAHULUAN}

\section{Latar Belakang Masalah}

Mutu merupakan suatu usaha untuk memenuhi atau melebihi harapan pelanggan, baik dari segi produk, tenaga kerja, proses, maupun lingkungan (Nasution, 2015). Mutu merupakan suatu hal yang harus dipenuhi oleh suatu perusahaan/organisasi dalam rangka mencapai keberhasilan pelaksanaan tugas dan tanggung jawabnya untuk memenuhi kebutuhan dan keinginan pelanggan. Oleh karena itu, setiap perusahaan dan organisasi akan selalu berupaya untuk meningkatkan mutu produk/jasa yang dihasilkannya.

Menurut Crosby (2008), produk yang bermutu adalah produk yang memiliki kesesuaian dengan persyaratan-persyaratan tertentu. Persyaratan tersebut merupakan standar mutu yang dibuat dan ditetapkan oleh organisasi yang terdapat di dalam sistem manajemen mutu (SMM). SMM itu sendiri menyediakan struktur organisasi, proses, prosedur serta sumber daya yang dibutuhkan untuk menunjukkan komitmen suatu organisasi dalam menjaga mutu produk yang dihasilkannya (Lloyd's Register Quality Assurance, 2017).

Salah satu standar SMM yang menjadi tolok ukur global adalah ISO 9001 yang merupakan pedoman dalam menjalankan proses bisnis hingga menciptakan produk unggul yang dapat memuaskan para pelanggan (Hadiwiardjo dan Sulistijarningsih, 2008). ISO 9001 telah diadopsi oleh 982.832 organisasi pada akhir 2008 di seluruh dunia (ISO, 2008). Saat ini, penerapan ISO 9001 juga telah merambah ke sektor nonbisnis, termasuk sektor pemerintah (Rakhmawati dkk., 2014). Hal ini dapat terjadi karena ISO 9001 merupakan standar generik yang dapat diterapkan pada setiap jenis organisasi, terlepas dari sifat organisasinya (publik atau swasta), produk yang dihasilkannya (barang atau jasa), ataupun ukuran organisasinya (skala besar atau kecil) (ISO, 2008).

Lembaga Kebijakan Pengadaan Barang/Jasa Pemerintah (LKPP) merupakan lembaga pemerintah nonkementerian yang berada di bawah dan bertanggungjawab kepada presiden. Berdasarkan peran dan fungsinya untuk mendorong peningkatan efisiensi dan efektivitas belanja pemerintah serta merumuskan kebijakan di bidang pengadaan barang/jasa pemerintah, LKPP melaksanakan reformasi birokrasi yang menjadi program nasional. Hal ini sesuai dengan amanat dalam Peraturan Presiden Nomor 81 Tahun 2010 tentang Grand Design yang menyatakan bahwa seluruh Kementerian/Lembaga/Pemerintah Daerah perlu melaksanakan reformasi dalam rangka mencapai tata kelola pemerintah yang baik. Pencapaian tata kelola tersebut harus diselaraskan dengan peningkatan pelayanan sesuai dengan UU Nomor 25 Tahun 2009 tentang Pelayanan Publik. Penyelarasan peningkatan 
pelayanan tersebut dilakukan melalui penerapan sistem manajemen mutu guna meningkatkan efektivitas dan efisiensi yang menjadi salah satu sasaran reformasi birokrasi.

Direktorat Pelatihan Kompetensi sebagai salah satu unit kerja LKPP telah memperoleh sertifikat ISO 9001:2015 melalui hasil asesmen pada bulan Juni 2017. Melalui ISO 9001:2015, semua kegiatan pelayanan telah memiliki Standard Operating Procedure (SOP) tersendiri. Capaian sertifikasi tersebut juga menunjukkan bahwa LKPP berkontribusi secara langsung dalam reformasi birokrasi yang sedang dijalankan oleh pemerintahan (LKPP, 2017). Meskipun demikian, terdapat sebagian rekomendasi sertifikat ISO pada suatu organisasi yang belum memiliki pengimplementasian yang dilakukan secara sempurna.

Secara umum, kegiatan pelayanan yang dilakukan oleh Direktorat Pelatihan Kompetensi LKPP telah berjalan dengan baik, terutama seiring dengan diimplementasikannya ISO 9001:2015 klausul operasi pada unit kerja tersebut. Akan tetapi, unit kerja tersebut masih mengalami berbagai permasalahan, seperti masalah kerusakan sarana kantor dan kurangnya pemeliharaan sarana tersebut yang pada akhirnya menimbulkan ketidaknyamanan bagi para pengguna gedung. Oleh karena itu, perlu dilakukan suatu penelitian untuk menganalisis kesesuaian antara sistem manajemen mutu yang dilakukan oleh Direktorat Pelatihan Kompetensi LKPP dengan subklausul operasi pada ISO 9001:2015. Selain itu, penelitian juga perlu dilakukan untuk menganalisis berbagai permasalahan yang dihadapi oleh Direktorat Pelatihan Kompetensi LKPP dalam memenuhi kesesuaian subklausul ISO 9001:2015 serta mengidentifikasi langkah atau alternatif tindakan yang tepat untuk memecahkan berbagai permasalahan tersebut. Hal-hal tersebut perlu diteliti sedemikian rupa untuk menjamin bahwa unit kerja dari instansi yang dimaksud benar-benar telah memenuhi persyaratan dan standar ISO.

\section{TINJAUAN PUSTAKA}

\section{Definisi Mutu}

Menurut Assauri (2008), mutu diartikan sebagai faktor-faktor di dalam suatu barang/hasil yang menyebabkan barang/hasil tersebut sesuai dengan tujuan pembuatannya. Prawirosentono (2007) mendefinisikan mutu sebagai keadaan fisik, fungsi, dan sifat suatu produk yang dapat memenuhi selera dan kebutuhan konsumen dengan memuaskan nilai uang yang telah dikeluarkan.

Menurut Goetsch dan Davis (2008), mutu adalah kondisi dinamik dari produk, jasa, orang, proses, dan lingkungan yang mencapai atau melebihi harapan. "Keadaan dinamik" merujuk pada realita bahwa sesuatu yang diyakini bermutu dapat dan seringkali berubah 
seiring pergantian waktu dan kondisi lingkungan. Unsur "produk, jasa, orang, proses, dan lingkungan", menunjukkan bahwa mutu tidak hanya berlaku bagi produk dan jasa yang disediakan, tetapi juga berlaku bagi orang dan proses yang menyediakan produk dan jasa itu serta lingkungan di mana produk dan jasa tersebut disediakan.

Menurut Nasution (2015:3), terdapat beberapa persamaan dari definisi mutu yang dikemukakan para ahli, yaitu dalam elemen-elemen sebagai berikut.

1. Mutu mencakup usaha memenuhi atau melebihi harapan pelanggan.

2. Mutu mencakup produk, tenaga kerja, proses dan lingkungan.

3. Mutu merupakan kondisi yang selalu berubah (misalnya apa yang dianggap berkualitas saat ini mungkin dianggap kurang berkualitas pada masa mendatang).

\section{Faktor-Faktor yang Mempengaruhi Mutu}

Menurut Assauri (2008:203) tingkat mutu ditentukan oleh beberapa faktor berikut.

1. Fungsi Suatu Barang

Dalam memproduksi suatu produk, perusahaan perlu memperhatikan fungsi penggunaannya agar produk yang dihasilkan dapat memenuhi fungsi tersebut dan membuat konsumen merasa puas. Berdasarkan fungsinya, mutu yang hendak dicapai dari suatu produk meliputi kecepatan, keawetan, kegunaan, berat, bunyi, kemudahan dalam perawatannya, serta kepercayaannya.

2. Wujud Luar

Salah satu faktor penting yang sering digunakan konsumen untuk menentukan mutu barang saat pertama kali melihatnya adalah wujud luar barang tersebut. Terkadang, meskipun secara teknis barang yang dihasilkan telah canggih, jika wujud luarnya kuno atau kurang dapat diterima, maka konsumen dapat tidak menyukai barang tersebut karena menganggap mutunya belum memenuhi syarat. Faktor wujud luar suatu barang dapat berupa bentuk, warna, susunan (seperti pengemasan), dan sebagainya.

3. Biaya Barang Tersebut

Produk dengan biaya atau harga yang relatif lebih mahal cenderung bermutu relatif lebih baik. Sebaliknya, produk dengan biaya atau harga yang relatif lebih murah cenderung bermutu relatif kurang baik. Hal tersebut terjadi karena produk bermutu baik cenderung membutuhkan biaya produksi yang relatif lebih mahal. 


\section{Manfaat Mutu}

Tampubolon (2012:82) menjelaskan bahwa mutu bermanfaat bagi perusahaan dalam menentukan hal-hal berikut.

1. Reputasi Perusahaan (Company Reputation)

Perusahaan yang berkedudukan sebagai pemimpin pasar (market leader) biasanya memiliki mutu yang lebih baik daripada para pesaingnya. Sementara itu, apabila perusahaan hanya berkedudukan sebagai pengikut pasar (market follower), maka perusahaan perlu mengendalikan mutu produknya menjadi lebih baik lagi (market reposition).

2. Pertanggung jawaban Produk (Product Liability)

Pertanggung jawaban produk merupakan suatu tantangan bagi perusahaan dalam memasarkan suatu produk. Apabila suatu produk menimbulkan permasalahan bagi pelanggan atau pasar, maka perusahaan yang memproduksinya akan bertanggung jawab secara moral dan material terhadap permasalahan yang ditimbulkan tersebut.

3. Aspek Global (Global Implication)

Di era globalisasi, setiap produk yang dipasarkan harus memiliki mutu yang mampu bersaing secara global. Desain produk juga harus disesuaikan dengan permintaan pasar internasional. Hal tersebut menunjukkan bahwa aspek global akan berpengaruh secara langsung terhadap mutu dari suatu produk.

\section{Dimensi Mutu}

Menurut Tjiptono dan Diana (2008:27), mutu barang dapat dilihat dari dimensi performa (performance),keistimewaan (features), keandalan (reliability), konformasi (conformance), daya tahan (durability), kemampuan pelayanan (service ability), estetika (aesthetics), dan kualitas yang dipersepsikan pelanggan (perceived quality).

Menurut Parasuraman, et al. (2008), mutu jasa terdiri dari dimensi bukti langsung (tangibles), keandalan (reliabity), daya tanggap (responsiveness),jaminan (assurance), dan empati.

\section{Manajemen Mutu Terpadu}

Manajemen mutu terpadu (Total Quality Management) merupakan filosofi tentang perbaikan secara terus-menerus yang dapat memberikan seperangkat alat praktis dalam memenuhi kebutuhan, keinginan dan harapan para pelanggannya, baik di saat ini maupun di 
masa mendatang (Sallis, 2006). Menurut Crocker, et al. (2010), manajemen mutu terpadu bertujuan untuk meningkatkan komunikasi, terutama antara karyawan lini dan manajemen serta mencari dan memecahkan persoalan.

\section{Alat Pengendalian Mutu}

Pada tahun 1960, Ishikawa memperkenalkan tujuh alat pengendali mutu (seven tools for quality control) di Jepang. Dikutip dari Sulaeman (2014), tujuh alat pengendali mutu yang diperkenalkan Ishikawa tersebut antara lain sebagai berikut.

1. Lembar pengecekan (checksheet), yaitu lembaran yang biasanya berbentuk formulir dengan item-item yang diperlukan yang berguna untuk mengumpulkan data hasil pemeriksaan.

2. Histogram, yaitu diagram yang terdiri dari grafik balok yang menggambarkan penyebaran data.

3. Diagram sebab akibat (fishbone diagram), yaitu diagram yang menggambarkan hubungan antara karakteristik mutu dan faktor penyebabnya.

4. Diagram pareto, yaitu alat yang menunjukkan permasalahan dengan prioritas tertinggi.

5. Diagram pencar, yaitu diagram yang menggambarkan hubungan antarfaktor atau data.

6. Diagram aliran, yaitu diagram yang menggambarkan cara menjalankan suatu program, mulai dari awal hingga akhir.

7. Diagram kendali, yaitu metode statistik yang menggambarkan adanya variasi penyimpangan akibat adanya sebab umum dan khusus.

\section{Sistem Manajemen Mutu dan ISO 9001:2015}

Menurut Gaspersz (2013), Sistem Manajemen Mutu (Quality Management System QMS) adalah sekumpulan prosedur terdokumentasi dan praktek standar untuk manajemen sistem yang bertujuan menjamin kesesuaian suatu proses dan produk terhadap kebutuhan persyaratan tertentu yang ditentukan oleh pelanggan dan organisasi.

Sistem manajemen mutu yang diakui secara internasional adalah ISO (International Standard Organizations). ISO memiliki beberapa seri yang disesuaikan dengan bidang yang dikelola oleh suatu organisasi. ISO 9001 merupakan suatu seri dari standar-standar internasional untuk sistem kualitas yang menspesifikasikan persyaratan serta rekomendasi desain dan penilaian dari suatu sistem manajemen dengan tujuan untuk menjamin bahwa pemasok (perusahaan) akan menyerahkan barang dan/atau jasa yang memenuhi persyaratan (Nasution, 2015). 
ISO 9001:2015 merupakan revisi dari versi ISO 9001:2008 yang telah resmi dirilis pada September 2015. Salah satu perubahan mendasar pada ISO 9001:2015 yaitu mengenai prinsip-prinsip dalam mengimplementasikan sistem manajemen mutu. Sebelumnya, ISO 9001:2008 mengacu pada delapan prinsip manajemen mutu. Sementara itu, ISO 9001:2015 menetapkan hanya tujuh prinsip dalam menjalankan manajemen mutu. Berikut ini merupakan tujuh prinsip sistem manejemen mutu berdasarkan ISO 9001:2015.

1. Fokus Pelanggan (Customer Focus)

Prinsip ini merupakan fokus utama dari manajemen mutu, yakni setiap organisasi harus dapat memenuhi persyaratan pelanggan. Bahkan, sebaiknya organisasi dapat memberikan produk atau jasa yang melebihi harapan para pelanggannya.

2. Kepemimpinan (Leadership)

Prinsip kepemimpinan menjelaskan bahwa pemimpin di semua level organisasi harus mempunyai kesatuan tujuan dan arah, serta menciptakan kondisi di mana setiap pegawai terlibat dalam mencapai sasaran mutu organisasi.

3. Keterlibatan Orang (Engagement of People)

Prinsip Engagement of People merupakan nama baru prinsip manajemen mutu yang pada ISO 9001:2008 disebut prinsip Involvement of People. Prinsip ini menjelaskan bahwa dalam suatu organisasi setiap pegawai merupakan pegawai kompeten, dapat diberdayakan, dan dapat dilibatkan dalam menjalankan proses bisnisnya.

4. Pendekatan Proses (Process Approach)

Pada dasarnya, prinsip ini menjelaskan bahwa sistem manajemen mutu dibangun berdasarkan hubungan proses yang saling terkait dan bersama-sama mengarah pada pencapaian tujuan organisasi yang merefleksikan kepuasan dari pihak-pihak yang berkepentingan (Rundle, 2015).

5. Perbaikan (Improvement)

Prinsip ini menjelaskan bahwa kesuksesan suatu organisasi dapat dicapai dengan fokus perbaikan yang berkelanjutan karena tindakan perbaikan tersebut dapat mempertahankan tingkat kinerja organisasi dan bereaksi terhadap perubahan yang terjadi baik dalam kondisi internal maupun eksternal organisasi, serta dapat menciptakan peluang baru.

6. Pengambilan Keputusan Berdasarkan Bukti (Evidence-Based Decision Making)

Prinsip ini menjelaskan bahwa setiap organisasi harus mengambil keputusan berdasarkan hasil analisis dan evaluasi data serta informasi. 
7. Manajemen Relasional (Relationship Management)

Prinsip ini menjelaskan bahwa untuk mencapai kesuksesan yang berkelanjutan, organisasi harus mengelola hubungan dengan berbagai pihak yang berkepentingan.

\section{Langkah-langkah Penerapan ISO 9001}

Menurut Gasperz (2013:325), berikut ini merupakan langkah-langkah yang perlu dilakukan untuk memperoleh sertifikat ISO 9000.

1. Memperoleh komitmen dari manajemen puncak.

2. Membentuk komite pengarah (steering committee) atau koordinator ISO.

3. Mempelajari standar-standar dan menilai kebutuhan-kebutuhan ISO 9000.

4. Melakukan pelatihan terhadap semua staf organisasi perusahaan itu.

5. Memulai tinjauan ulang manajemen.

6. Identifikasi kebijaksanaan kualitas, prosedur-prosedur, dan instruksi-instruksi yang dibutuhkan.

7. ISO $9000 \mathrm{itu}$, sekali sistem ISO 9000 dibangun, sistem kualitas yang ada selama ini harus dimodifikasi dan dokumentasi pendukung dibuat sehingga implementasi menjadi sukses.

8. Memulai audit sistem kualitas perusahaan.

9. Memilih registrar.

10. Registrasi.

\section{Kerangka Analisis}

Berdasarkan kerangka kerja Analytical Hierarchy Process (AHP), penelitian ini diawali dengan pengumpulan data dan informasi yang digunakan untuk menyusun struktur hierarki.Struktur hierarki disusun sesuai dengan kebutuhan dan didasarkan pada teori dalam literatur dan hasil wawancara dengan pihak perusahaan atau organisasi yang bertindak sebagai pengambil keputusan. Kuesioner diberikan untuk mengetahui pembobotan setiap unsur pada setiap tingkatan dalam hierarki. Data yang diperoleh dari responden kemudian diproses dan hasil pengolahannya dianalisis serta disajikan dalam bentuk uraian, gambar dan tabel.

Penggunaan AHP sebagai alat analisis dalam penelitian ini dikarenakan metode ini mampu menyederhanakan permasalahan kompleks yang tidak terstruktur, strategik dan dinamik menjadi bagian-bagiannya, serta menyusunnya ke dalam hierarki.Selain itu, metode ini dapat disajikan secara grafik yang dapat memudahkan pihak-pihak yang terlibat dalam pengambilan keputusan (Marimin, 2008). 


\section{METODE PENELITIAN}

\section{Objek Penelitian}

Objek dalam penelitian ini adalah implementasi ISO 9001:2015 klausul operasi pada Direktorat Pelatihan Kompetensi LKPP. Subjek penelitian ini adalah unit kerja Direktorat Pelatihan Kompetensi LKPP dengan pertimbangan bahwa unit kerja tersebut telah memperoleh sertifikat ISO 9001:2015 pada bulan Juni 2017. Penelitian ini merupakan penelitian evaluatif yang mengevaluasi implementasi ISO 9001:2015 klausul operasi yang terdiri atas subklausul komunikasi pelanggan, penentuan persyaratan produk dan jasa, perubahan persyaratan pada produk dan jasa, serta preservasi.

\section{Sumber dan Jenis Data}

Data yang digunakan dalam penelitian ini adalah data primer dan sekunder. Data primer diperoleh melalui kegiatan wawancara, pengamatan langsung (observasi) dan kuesioner, sedangkan data sekunder diperoleh dari dokumen internal, studi literatur dan data lain yang berkaitan dengan topik penelitian.

Jenis data dalam penelitian ini adalah data cross section, yaitu data yang dikumpulkan pada suatu waktu tertentu yang dapat menggambarkan keadaan populasi pada waktu tersebut.

\section{Populasi dan Sampel}

Penarikan sampel dalam penelitian ini dilakukan dengan menggunakan teknik nonprobability sampling, dengan jenis purposive sampling, dimana pemilihan sampel didasarkan atas ciri-ciri tertentu yang dipandang mempunyai sangkut paut yang erat dengan ciri-ciri tertentu yang sudah diketahui sebelumnya (Margono, 2010).

Penelitian ini menggunakan dua kriteria penarikan sampel, yaitu: (1) sampel merupakan perwakilan dari tiap tingkatan manajemen pada Direktorat Pelatihan Kompetensi LKPP, dan (2) sampel merupakan pihak yang paling kompeten serta memiliki pemahaman paling luas mengenai penerapan ISO 9001:2015 pada Direktorat Pelatihan Kompetensi LKPP yang terdiri atas tiga orang yaitu satu orang direktur, satu orang kepala subdirektorat dan satu orang kepala seksi.

\section{Metode Analisis}

Langkah pertama yang dilakukan dalam penelitian ini adalah mempelajari struktur hierarki dalam AHP untuk menyusun hierarkinya. Kemudian, menganalisis implementasi kesesuaian subklausul ISO 9001:2015 melalui kegiatan wawancara, pengamatan langsung 
(observasi) dan dokumentasi internal, serta menganalisis permasalahan yang terjadi dalam pemenuhan kesesuaian subklausul ISO dengan menggunakan Fishbone Diagram. Setiap unsur dalam tingkatan AHP diperoleh berdasarkan hasil diskusi dengan pihak manajemen Direktorat Pelatihan Kompetensi LKPP. Tingkatan yang diidentifikasi dalam hierarki AHP adalah faktor atau kriteria masalah, aktor, tujuan dan alternatif tindakan yang dapat dilakukan.

Hasil wawancara, pengamatan langsung serta dokumentasi internal digunakan untuk menyusun angket yang diberikan kepada informan. Pemilihan informan dilakukan dengan menetapkan kriteria tertentu, yaitu pihak manajerial yang memiliki pemahaman mengenai pelaksanaan implementasi sistem manajemen mutu ISO di Direktorat Pelatihan Kompetensi LKPP.

Hasil dari pengisian angket adalah matriks pendapat individu (MPI) yang diolah dengan metode AHP untuk mengetahui bobot dari setiap unsur hierarki. Hasil pengisian angket oleh responden kemudian diolah dengan bantuan software Expert Choice 2000 dan Microsoft Excel 2007 untuk diketahui pembobotan pada setiap elemen hierarkinya dengan batas inkonsistensi 10\%. Jika MPI tidak konsisten, maka harus direvisi dengan mencari deviasi RMS (Root Mean Square) dan MAD (Median Absolute Deviation). Setelah MPI dinyatakan konsisten, akan dilakukan penggabungan matriks yang kemudian diukur kembali dengan pengolahan horizontal dan vertikal sesuai mekanisme AHP.

Hasil pengolahan horizontal adalah keterkaitan dan tingkat pengaruh antara unsur pada satu tingkat hierarki dengan hierarki di atasnya. Sementara itu, hasil pengolahan vertikal adalah alternatif tindakan yang dapat dilakukan oleh pihak manajemen Direktorat Pelatihan Kompetensi LKPP dalam rangka implementasi ISO 9001:2015.

\section{Model Analisis}

Berdasarkan uraian di atas, berikut ini merupakan model analisis yang digunakan dalam penelitian ini. 


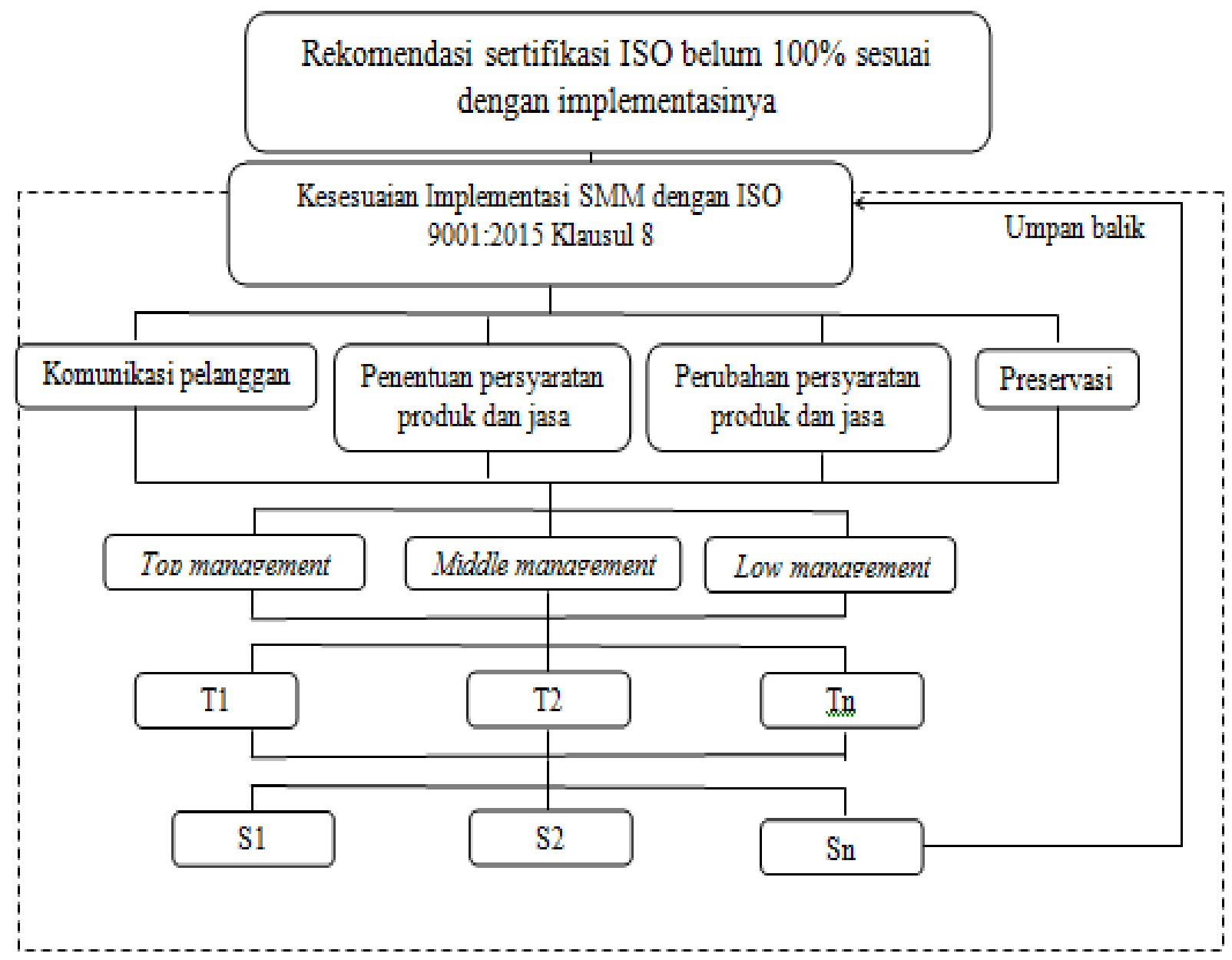

Gambar 1. Model Analytical Hierarchy Process (AHP)

\section{HASIL PENELITIAN DAN PEMBAHASAN}

\section{Implementasi ISO 9001:2015 pada Direktorat Pelatihan Kompetensi LKPP}

Implementasi ISO 9001:2015 dijelaskan melalui subklausul ISO itu sendiri, khususnya subklausul yang terdapat pada klausul operasi. Dalam penelitian ini, implementasi subklausul yang dibahas terdiri dari subklausul komunikasi pelanggan, subklausul penentuan persyaratan produk dan jasa, subklausul perubahan persyaratan pada produk dan jasa, serta subklausul preservasi. Implementasi subklausul tersebut pada LKPP akan dijabarkan sebagai berikut.

\section{Subklausul 8.2.1 Komunikasi Pelanggan}

Direktorat Pelatihan Kompetensi LKPP mengatur komunikasi dengan pelanggan melalui hal-hal sebagai berikut.

a. Penyediaan informasi yang berkaitan dengan produk dan jasa.

b. Penanganan pertanyaan, permintaan termasuk perubahan yang diajukan oleh pelanggan. 
c. Memperoleh umpan balik pelanggan terkait produk dan jasa, termasuk keluhan pelanggan.

d. Penanganan atau pengendalian kepemilikan pelanggan.

Pengelolaan mutu yang dilakukan oleh unit kerja Direktorat Pelatihan Kompetensi LKPP terkait dengan subklausul ini adalah sebagai berikut.

a. Mengimplementasikan mekanisme penanganan umpan balik, konsultasi dan keluhan pelanggan melalui Pelayanan Terpadu Satu Pintu (PTSP - One Stop Service) yang terdiri dari delapan (8) loket yang ada di lantai mezzanine gedung LKPP. Setelah informasi diterima dari pelanggan, baik mengenai keluhan maupun konsultasi, PTSP akan secara tanggap menindaklanjuti informasi tersebut dan menghubungi unit kerja terkait agar dapat segera melakukan pengambilan tindakan atau solusi yang tepat. Pelayanan dalam PTSP ini terkelola dengan baik sehingga tidak menimbulkan antrian yang panjang.

b. Direktorat Pelatihan Kompetensi LKPP juga menyediakan informasi lengkap yang berkaitan dengan produk dan jasa yang ditawarkan yang dapat diakses dengan mudah melalui website, yaitu pada portal Deputi PPSDM LKPP yang merupakan portal khusus untuk kedeputian tersebut. Pelanggan diharuskan untuk melakukan registrasi atau pendaftaran pada portal tersebut terlebih dahulu sebelum dapat masuk ( $\log$ in) untuk memperoleh seluruh informasi yang diperlukan mengenai ketiga direktorat yang membawahi kedeputian PPSDM.

c. Terkait dengan penanganan atau pengendalian kepemilikan pelanggan, Direktorat Pelatihan Kompetensi memastikan bahwa arsip data-data yang diserahkan oleh pelanggan terkendali dan terkelola dengan baik serta terhindar dari kemungkinan kerusakan. Arsip data-data pelanggan pada tahun 2005 yang saat itu masih migrasi dari BAPPENAS hingga tahun 2009 telah terekam di dalam database. Agar terhindar dari kerusakan arsip, Direktorat Pelatihan Kompetensi juga melakukan pencadangan (back up) arsip digital dengan sistem $F X$-Series.

\section{Subklausul 8.2.2 Penentuan Persyaratan pada Produk dan Jasa}

Dalam menentukan persyaratan produk dan jasa yang ditawarkan kepada pelanggan, Direktorat Pelatihan Kompetensi LKPP memastikan bahwa persyaratan produk dan jasa yang ditetapkan telah mencakup: (a) persyaratan peraturan dan perundang-undangan yang berlaku; dan (b) persyaratan lain yang dianggap perlu oleh organisasi. 


\section{Subklausul 8.2.4 Perubahan Persyaratan pada Produk dan Jasa}

Terkait dengan perubahan persyaratan pada produk dan jasa, Direktorat Pelatihan Kompetensi selalu memastikan hal-hal sebagai berikut.

a. Perubahan pada persyaratan produk dan jasa selalu mengikuti peraturan yang berlaku.

b. Apabila persyaratan produk dan jasa diubah, maka organisasi harus memastikan bahwa informasi terdokumentasi yang relevan telah diubah.

c. Apabila persyaratan produk dan jasa diubah, maka terdapat pemberitahuan kepada personil terkait mengenai perubahan persyaratan tersebut yang dilakukan melalui sosialisasi langsung baik dengan mengundang seluruh K/L/D/I (Kementerian/Lembaga/Satuan Kerja Perangkat Daerah/Institusi) untuk datang ke LKPP maupun melakukan sosialisasi melalui website, ataupun e-mail.

\section{Subklausul 8.5.4 Preservasi}

Menurut subklausul ini, Direktorat Pelatihan Kompetensi LKPP selalu mengupayakan penjagaan output selama penyediaan produksi dan jasa dengan memastikan kesesuaiannya dengan SOP (Standard Operating Procedure) yang telah disusun dan akan dilakukan revisi apabila terdapat perubahan-perubahan. Penyusunan SOP itu sendiri bertujuan untuk mencapai sasaran dan tujuan organisasi, karena selain ditentukan oleh ketersediaan sumber daya manusia yang memadai, kesuksesan pencapaian sasaran dan tujuan suatu organisasi juga ditentukan oleh mekanisme dan prosedur kerja yang terstandarisasi dalam rangka menjamin tingginya efisiensi, efektivitas, dan kualitas pelayanan yang diberikan oleh organisasi tersebut. Direktorat Pelatihan Kompetensi LKPP juga melakukan penjagaan produk dan jasa secara konsisten melalui kegiatan briefing dengan notulensi rapat yang terdokumentasi dan terpelihara.

\footnotetext{
Aktor

Aktor adalah pihak-pihak yang berkaitan dan bertanggung jawab dalam pengimplementasian ISO 9001:2015 pada Direktorat Pelatihan Kompetensi LKPP. Dalam Direktorat Pelatihan Kompetensi LKPP ini tidak ada tim khusus ISO, tetapi semua SDM dalam unit kerja ini memiliki peran dalam pengimplementasian ISO 9001:2015.

Terdapat tiga pihak yang bertanggungjawab dalam pengimplementasian ISO 9001:2015 pada Direktorat Pelatihan Kompetensi LKPP, yaitu sebagai berikut.
} 


\section{Top Management}

Top management atau manajemen puncak pada Direktorat Pelatihan Kompetensi LKPP dipegang oleh Direktur Pelatihan Kompetensi yang berperan dalam mengkoordinasikan, merencanakan, menentukan dan memutuskan kebijakan yang berkaitan dengan pengimplementasian ISO 9001:2015 pada unit kerja Direktorat Pelatihan Kompetensi LKPP. Seluruh kebijakan dan kegiatan yang dilakukan oleh unit kerja tersebut harus mendapat persetujuan dari top management. Selain itu, top management juga berperan dalam menyiapkan rumusan pedoman pelatihan kompetensi pengadaan barang/jasa pemerintah dan pengelolaan sumber daya pembelajaran.

\section{Middle Management}

Pada middle management atau manajemen tingkat menengah di unit kerja tersebut, terdapat dua orang yang bertanggung jawab dalam pengimplementasian ISO 9001:2015, yaitu Kepala Subdirektorat Program Pelatihan dan Kepala Subdirektorat Sumber Daya Pembelajaran. Pihak ini berperan dalam mengimplementasikan strategi, kebijakan mutu, dan kebijakan lainnya yang diambil oleh top management. Selain itu, middle management juga berperan dalam pembuatan konsep rumusan pedoman, program dan kurikulum, pemantauan evaluasi dari pelatihan kompetensi PBJP, diseminasi, pembinaan pengajar pengadaan dan lembaga pelatihan, pengendalian mutu, asesor akreditasi lembaga pelatihan, serta akreditasi lembaga pelatihan PBJP.

\section{Low Management}

Pada low management atau manajemen tingkat bawah di unit kerja ini terdapat empat orang yang bertanggung jawab dalam pengimplementasian ISO 9001:2015, yaitu Kepala Seksi Materi Pelatihan, Kepala Seksi Evaluasi Pelatihan, Kepala Seksi Pengajar Pengadaan, dan Kepala Seksi Lembaga Pelatihan. Pihak ini berperan sebagai pelaksana yang melakukan kegiatan sesuai dengan prosedur atau instruksi kerja yang telah ditetapkan. Selain itu, low management juga memiliki tugas menyiapkan bahan rumusan pedoman dari pembinaan, pelatihan, pemantauan dan evaluasi pengajar pengadaan, asesor akreditasi lembaga pelatihan, pelaksanaan pendidikan dan pelatihan jabatan fungsional pengelola pengadaan barang/jasa, dan pengelolaan informasi serta diseminasi pengetahuan pengadaan barang/jasa. 


\section{Tujuan}

Direktorat Pelatihan Kompetensi LKPP memiliki dua tujuan utama yang ingin diraih dalam kaitannya dengan pengimplementasian ISO 9001:2015, yaitu sebagai berikut.

\section{Peningkatan Mutu Pelayanan}

Berdasarkan Undang-Undang Nomor 25 Tahun 2009 tentang Pelayanan Publik, mutu pelayanan publik merupakan hal yang harus selalu ditingkatkan oleh penyelenggara pelayanan publik. Peningkatan mutu pelayanan merupakan salah satu upaya untuk menjalankan amanat undang-undang mengenai pelaksanaan reformasi birokrasi dalam rangka mewujudkan tata kelola pemerintah yang baik (good governance). LKPP sebagai salah satu penyelenggara pelayanan publik telah mengimplementasikan ISO 9001:2015 pada unit kerja Direktorat Pelatihan Kompetensi yang diharapkan mampu meningkatkan mutu pelayanan yang diberikan oleh unit kerja tersebut.

\section{Peningkatan Kompetensi Pengadaan Barang/Jasa}

Peningkatan kompetensi pengadaan barang/jasa perlu dicapai dalam rangka meningkatkan kualitas pengadaan barang/jasa, baik di tingkat pusat, maupun di tingkat desa. Tujuan ini selaras dengan visi dari Direktorat Pelatihan Kompetensi LKPP itu sendiri.

\section{Alternatif Tindakan}

Dalam kaitannya dengan tujuan yang ingin diraih di atas, berikut ini merupakan alternatif tindakan yang dapat dilakukan oleh Direktorat Pelatihan Kompetensi LKPP.

\section{Pendidikan dan Pelatihan (Diklat)}

Penyelenggaraan kegiatan diklat diharapkan dapat meningkatkan pengetahuan, keterampilan dan kemampuan kerja pegawai terkait implementasi ISO 9001:2015. Kegiatan diklat di unit kerja Direktorat Pelatihan Kompetensi LKPP dilaksanakan selama 2-3 kali setahun. Pelaksanaan diklat yang sering dilakukan antara lain gugus kendali mutu, pelatihanpelatihan dengan peningkatan kinerja SDM, pelatihan di luar LKPP, dan kegiatan konsinyasi yang bertujuan untuk melatih kekompakan tim. Kegiatan diklat tersebut bertujuan untuk mengembangkan kompetensi dan membekali pengetahuan SDM mengenai ISO, serta membentuk pola pikir dan budaya kerja yang berintegritas dan mengedepankan pelayanan publik. Kompetensi yang diharapkan dari kegiatan diklat tersebut yaitu kinerja pegawai yang aktif. 
Akan tetapi, pelaksanaan kegiatan diklat tersebut terkadang tertunda karena belum adanya jadwal yang jelas mengenai pelaksanaannya, sehingga sering berbenturan dengan waktu kegiatan di luar LKPP yang tidak terkait dengan pelatihan dan ISO. Adanya kegiatan diklat yang lebih terjadwal diharapkan dapat menjaga intensitas penyelenggaraan diklat, khususnya yang berkaitan dengan pembekalan pengetahuan tentang ISO dan peningkatan kinerja pegawai, sehingga mampu mengarahkan pegawai untuk bekerja sesuai dengan sasaran mutu dan hal-hal lain yang berkaitan dengan ISO 9001:2015.

\section{Rapat Tinjauan Manajemen (RTM)}

Rapat tinjauan manajemen merupakan kegiatan yang wajib dilaksanakan oleh perusahaan atau organisasi yang sedang atau telah menerapkan sistem manajemen mutu ISO. Dalam kegiatan ini, dilakukan evaluasi atau penilaian peluang koreksi dan keperluan akan perubahan pada sistem manajemen mutu, termasuk kebijakan dan sasaran mutu, serta meninjau resiko. Tujuan dari pelaksanaan RTM pada Direktorat Pelatihan Kompetensi LKPP yaitu untuk mengetahui arah kebijakan organisasi, membahas isu-isu yang up to date dan mengontrol proses bisnis yang ada di unit kerja Direktorat Pelatihan Kompetensi untuk mengevaluasi kesesuaiannya dengan visi misi yang telah ditetapkan. Hasil pelaksanaan RTM adalah informasi mengenai isu-isu terkait dan tinjauan resiko yang akan dihadapi di masa mendatang.

\section{Analisis Fishbone Diagram}

Analisis fishbone diagram (diagram tulang ikan) atau biasa disebut dengan cause and effect diagram (diagram diagram sebab akibat) merupakan alat yang membantu mengidentifikasi hal-hal yang menyebabkan suatu masalah atau karakteristik kualitas tertentu. Berdasarkan pendekatan ini, terdapat beberapa faktor utama yang menyebabkan terjadinya masalah dalam implementasi dan pemenuhan kesesuaian subklausul ISO 9001:2015 pada Direktorat Pelatihan Kompetensi LKPP. Faktor-faktor tersebut terdiri dari man, machine, dan method yang dikelompokkan dalam diagram yang terdapat pada gambar di bawah ini. 


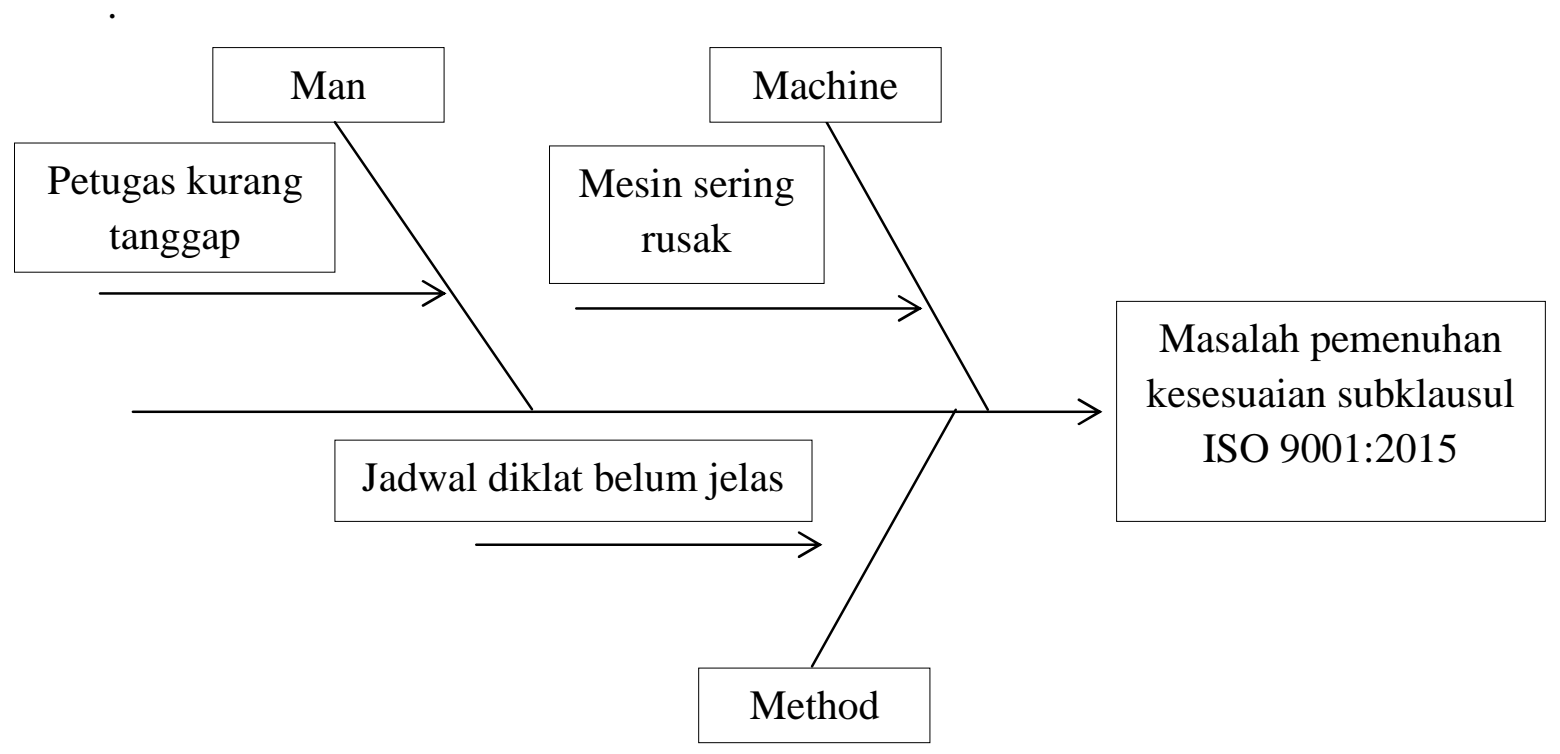

Gambar 2. Fishbone Diagram Permasalahan Pemenuhan Kesesuaian Subklausul ISO 9001:2015

Pada uraiannya sebelumnya, telah dijelaskan bahwa upaya Direktorat Pelatihan Kompetensi dalam memenuhi persyaratan yang terdapat dalam subklausul komunikasi pelanggan, penentuan persyaratan produk dan jasa, perubahan persyaratan pada produk dan jasa serta preservasi telah dilakukan dengan baik. Namun, implementasinya masih belum maksimal. Hal ini dikarenakan masih terdapat beberapa permasalahan yang terjadi. Berdasarkan gambar di atas, terdapat tiga faktor utama penyebab permasalahan dalam memenuhi kesesuaian subklausul ISO 9001:2015 pada Direktorat Pelatihan Kompetensi LKPP. Ketiga faktor tersebut dapat diuraikan sebagai berikut.

1. Man (manusia atau tenaga kerja)

Petugas kurang tanggap dalam mengatasi kerusakan yang terjadi pada mesin fotokopi, sehingga mesin yang rusak tidak ditangani dengan segera. Hal ini terjadi karena petugas kurang peduli terhadap prosedur mutu, misalnya yang ditunjukkan dengan tidak melakukan pemeliharaan mesin secara berkala.

2. Machine (mesin)

Mesin fotokopi sering mengalami kerusakan, sehingga kualitas hasil fotokopiannya menjadi kurang baik. Kerusakan pada mesin disebabkan oleh roller heat atau komponen pemanas yang cacat atau rusak karena terlambat diberi minyak. Minyak berfungsi sebagai pelumas roller heat agar suhunya stabil. Jika pelumasan terlambat, maka roller heat akan 
menjadi cacat sehingga kualitas hasil fotokopian menjadi rendah karena terkesan bergaris-garis. Jika kinerja mesin terganggu, maka kegiatan pelayanan dalam unit kerja Direktorat Pelatihan Kompetensi, seperti kegiatan pengarsipan data-data milik pelanggan, akan terhambat. Hal ini berkaitan dengan hierarki AHP tingkat dua mengenai subklausul komunikasi pelanggan.

3. Method (metode)

Penjadwalan kegiatan diklat internal terkait peningkatan pengetahuan tentang ISO seringkali belum terjadwal dengan jelas sehingga sering mengalami pengunduran akibat berbenturan dengan jadwal kegiatan di luar kantor yang tidak terkait dengan pelatihan dan ISO. Dalam rangka memaksimalkan upaya pelaksanaan diklat internal, diperlukan penjadwalan kegiatan yang jelas agar terhindar dari kemungkinan pengunduran kegiatan. Hal ini berkaitan dengan hierarki AHP tingkat empat, yaitu pelaksanaan diklat.

\section{Penyusunan Struktur Hierarki}

Model struktur hierarki yang digunakan dalam penelitian ini terdiri dari lima tingkat yang disajikan pada gambar 3. Tingkat pertama merupakan goal atau focus, yaitu kesesuaian implementasi SMM dengan ISO 9001:2015 klausul 8. Pemilihan fokus ini bertujuan untuk mengetahui alternatif tindakan yang dapat dilakukan oleh Direktorat Pelatihan Kompetensi LKPP guna mengefektifkan pemenuhan kesesuaian implementasi ISO 9001:2015 pada unit kerja tersebut.

Pada tingkat kedua, terdapat fokus atau kriteria masalah yang terdiri dari empat faktor, yaitu komunikasi pelanggan, penentuan persyaratan produk dan jasa, perubahan pada persyaratan produk dan jasa serta preservasi. Keempat faktor tersebut merupakan subklausul ISO yang terdapat pada klausul 8 ISO 9001:2015.

Pada tingkat ketiga, terdapat aktor yang terdiri dari top management, middle management, dan low management. Pemilihan ketiga aktor tersebut merupakan hasil diskusi dengan pihak organisasi. Setiap aktor tersebut memiliki peran yang sangat penting dalam pengimplementasian ISO 9001:2015.

Pada tingkat keempat, terdapat tujuan, yaitu hal-hal yang ingin diraih dari pengimplementasian ISO 9001:2015 yang antara lain meliputi meningkatkan mutu pelayanan yang diberikan oleh Direktorat Pelatihan Kompetensi baik internal maupun eksternal, serta meningkatkan kompetensi pengadaan barang dan jasa di seluruh K/L/D/I.

Pada tingkat kelima, terdapat alternatif tindakan yang disusun oleh Direktorat Pelatihan Kompetensi LKPP untuk menjamin efektivitas dan efisiensi pengimplementasian 
ISO 9001:2015. Berdasarkan hasil diskusi, alternatif tindakan tersebut meliputi pendidikan dan latihan (diklat) serta rapat tinjuan manajemen (RTM).

Susunan struktur hierarki kesesuaian implementasi SMM dengan ISO 9001:2015 klausul 8 pada Direktorat Pelatihan Kompetensi LKPP disajikan pada gambar sebagai berikut.

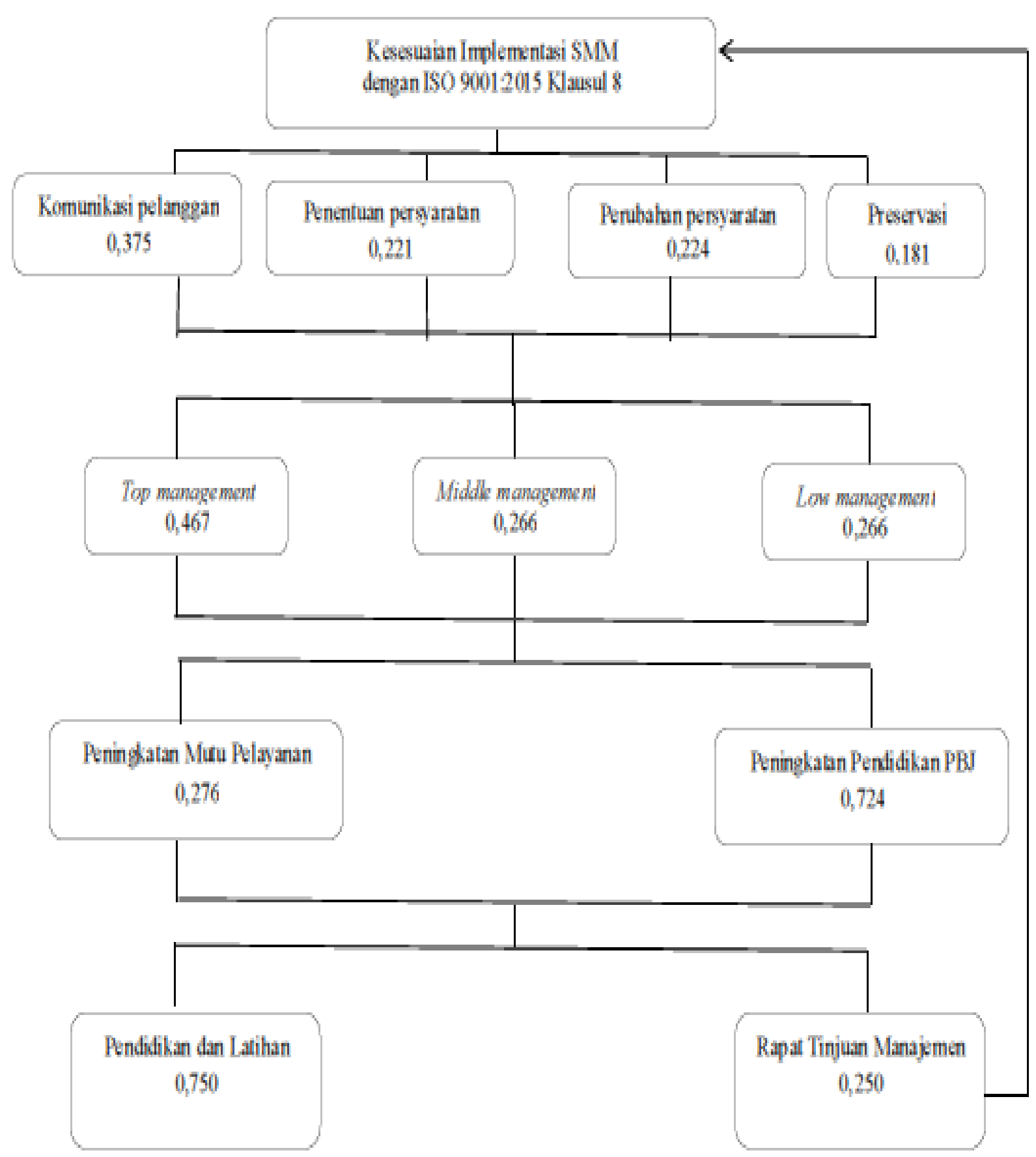

Gambar 3. Susunan Struktur Hierarki Kesesuaian Implementasi SMM dengan ISO 9001:2015 Klausul 8 


\section{Analisis Prioritas Faktor, Aktor, Tujuan, dan Alternatif Tindakan Berdasarkan Matriks Pendapat Gabungan}

Berdasarkan gambar di atas, struktur hierarki AHP terdiri dari lima level atau tingkatan dimana kesesuaian implementasi SMM dengan ISO 9001:2015 klausul 8 menjadi fokus atau goal yang terdapat pada tingkat 1 yang telah ditentukan dalam penelitian ini. Tingkatan selanjutnya mengenai urutan prioritas faktor dapat dilihat pada tabel sebagai berikut.

Tabel 1. Urutan Prioritas Faktor Berdasarkan Matriks Pendapat Gabungan

\begin{tabular}{|l|c|c|}
\hline \multicolumn{1}{|c|}{ Faktor } & Bobot & Prioritas \\
\hline Komunikasi pelanggan & 0,375 & 1 \\
\hline Penentuan persyaratan produk dan jasa & 0,221 & 3 \\
\hline Perubahan persyaratan pada produk dan jasa & 0,224 & 2 \\
\hline Preservasi & 0,181 & 4 \\
\hline
\end{tabular}

(Sumber: Data diolah, 2017)

Berdasarkan tabel di atas, komunikasi pelanggan berada pada prioritas pertama dengan bobot sebesar 0,375, perubahan persyaratan pada produk dan jasa berada pada prioritas kedua dengan bobot sebesar 0,224 , disusul oleh faktor penentuan persyaratan produk dan jasa yang berada pada prioritas ketiga dengan bobot sebesar 0,221 dan preservasi pada prioritas keempat dengan bobot sebesar 0,181.

Komunikasi pelanggan menjadi prioritas pertama karena merupakan hal yang penting dalam implementasi ISO 9001:2015. Terciptanya komunikasi yang baik dengan pelanggan akan mendorong kepuasan pelanggan. Sebaliknya, jalinan komunikasi yang kurang baik dengan pelanggan akan menimbulkan ketidakpuasan pelanggan dan keluhan.

Faktor prioritas kedua adalah perubahan persyaratan pada produk dan jasa. Perubahan tersebut seringkali terjadi akibat adanya perubahan peraturan perundang-undangan yang berlaku. Penyesuaian terhadap perubahan yang terjadi biasanya membutuhkan waktu yang cukup lama, sehingga hal ini seringkali menjadi kendala bagi instasnsi dan unit kerja.

Faktor prioritas ketiga adalah penentuan persyaratan produk dan jasa. Faktor ini menjadi prioritas karena mencakup persyaratan-persyaratan penting terkait dengan persyaratan peraturan dan perundang-undangan yang berlaku, serta persyaratan lain yang dianggap perlu oleh organisasi.

Faktor prioritas keempat adalah preservasi. Faktor ini memuat kegiatan untuk memastikan bahwa pelayanan yang akan diberikan kepada pelanggan telah sesuai dengan seluruh persyaratan yang ada, misalnya kegiatan briefing. Briefing juga dapat menghindari terjadinya kekurangan pada pelayanan yang diberikan. 
Tingkatan selanjutnya dari struktur hierarki kesesuaian implementasi SMM dengan ISO 9001:2015 klausul 8 adalah urutan prioritas aktor. Berikut ini merupakan tabel prioritasnya.

Tabel 2. Urutan Prioritas Aktor Berdasarkan Matriks Pendapat Gabungan

\begin{tabular}{|l|c|c|}
\hline \multicolumn{1}{|c|}{ Aktor } & Bobot & Prioritas \\
\hline Top management & 0,467 & 1 \\
\cline { 1 - 2 } Middle management & 0,266 & 2 \\
\hline Low management & 0,266 & \\
\hline
\end{tabular}

(Sumber: Data diolah, 2017)

Berdasarkan tabel di atas, top management menjadi prioritas pertama karena dalam implementasi ISO 9001:2015, top management merupakan pihak yang dituntut untuk berperan aktif dan bertanggung jawab dalam menetapkan kebijakan, sasaran strategis, komunikasi dan juga mendorong komitmen terhadap mutu. Top management harus memastikan bahwa tanggung jawab dan peran yang relevan harus diberikan, dikomunikasikan dan dipahami oleh organisasi. Oleh karena itu, top management memiliki peran yang sangat penting dalam implementasi ISO 9001:2015. Sementara itu, middle management dan low management berada pada prioritas yang sama, yaitu di urutan kedua. Hal ini terjadi karena middle management dan low management sama-sama memiliki peran aktif dalam mendukung, mengimplementasi dan melaksanakan kebijakan yang telah ditetapkan oleh top management.

Tingkatan selanjutnya dari struktur hierarki kesesuaian implementasi SMM dengan ISO 9001:2015 klausul 8 adalah urutan prioritas tujuan. Berikut ini merupakan tabel prioritasnya.

Tabel 3. Urutan Prioritas Tujuan Berdasarkan Matriks Pendapat Gabungan

\begin{tabular}{|l|c|c|}
\hline \multicolumn{1}{|c|}{ Tujuan } & Bobot & Prioritas \\
\hline Peningkatan mutu pelayanan & 0,276 & 2 \\
\hline Peningkatan kompetensi pengadaan barang/jasa & 0,724 & 1 \\
\hline
\end{tabular}

(Sumber: Data diolah, 2017)

Berdasarkan tabel di atas, peningkatan kompetensi pengadaan barang/jasa (PBJ) menjadi prioritas pertama dengan bobot sebesar 0,724, sedangkan peningkatan mutu pelayanan menjadi prioritas kedua dengan bobot sebesar 0,276. Hal ini dikarenakan berdasarkan pembiayaan Anggaran Pendapatan dan Belanja Desa (APBDesa), tata kelola pengadaan barang/jasa (PBJ) perlu ditingkatkan. Hal tersebut hanya dapat dicapai dengan ditingkatkannya kompetensi pengadaan barang/jasa yang merata, baik di tingkat pusat dan kota, maupun di tingkat desa. 
Prioritas kedua diduduki oleh peningkatan mutu pelayanan. Berdasarkan UndangUndang Nomor 25 Tahun 2009 tentang Pelayanan Publik, mutu pelayanan publik merupakan hal yang harus selalu ditingkatkan oleh penyelenggara pelayanan publik. Peningkatan mutu pelayanan merupakan salah satu upaya untuk menjalankan amanat undang-undang mengenai pelaksanaan reformasi birokrasi dalam rangka mewujudkan tata kelola pemerintah yang baik (good governance).

Tingkatan selanjutnya dari struktur hierarki kesesuaian implementasi SMM dengan ISO 9001:2015 klausul 8 adalah urutan prioritas alternatif tindakan. Berikut ini merupakan tabel prioritasnya.

Tabel 4. Urutan Prioritas Alternatif Tindakan

Berdasarkan Matriks Pendapat Gabungan

\begin{tabular}{|l|c|c|}
\hline \multicolumn{1}{|c|}{ Tujuan } & Bobot & Prioritas \\
\hline Pendidikan dan pelatihan (diklat) & 0,750 & 1 \\
\hline Rapat tinjauan manajemen & 0,250 & 2 \\
\hline
\end{tabular}

(Sumber: Data diolah, 2017)

Berdasarkan tabel di atas, diklat menjadi prioritas utama dalam alternatif tindakan dengan bobot sebesar 0,750 , sedangkan rapat tinjauan manajemen menjadi prioritas kedua dengan bobot sebesar 0,250. Hal ini dikarenakan kegiatan diklat yang intensif dapat meningkatkan kompetensi dan produktivitas pegawai, serta memperluas wawasan pegawai mengenai ISO yang akan memudahkan pegawai tersebut dalam mengimpelementasikan sistem manajemen mutu yang baik. Prioritas alternatif tindakan yang kedua adalah rapat tinjauan manajemen. Kegiatan ini memiliki peranan yang cukup penting karena bertujuan untuk mengetahui arah kebijakan organisasi dan meninjau resiko yang akan dihadapi oleh organisasi di masa mendatang. Pelaksanaan evaluasi melalui rapat tinjauan manajemen yang dilakukan secara intensif diyakini dapat meningkatkan efektivitas dan efisiensi pengimplementasian ISO 9001:2015.

\section{KESIMPULAN DAN SARAN}

\section{Kesimpulan}

Berdasarkan hasil penelitian, berikut ini merupakan kesimpulan yang dapat diambil.

1. Upaya untuk memenuhi kesesuaian dari setiap persyaratan yang terdapat dalam ISO 9001:2015 klausul operasi, khususnya subklausul komunikasi pelanggan, penentuan persyaratan produk dan jasa, perubahan persyaratan pada produk dan jasa, serta preservasi telah dilakukan dengan baik oleh Direktorat Pelatihan Kompetensi LKPP. 
2. Meskipun seluruh persyaratan yang terdapat dalam keempat subklausul tersebut telah dipenuhi dengan baik, pelaksanaannya masih belum optimal karena masih terjadi beberapa permasalahan.

3. Faktor utama yang memiliki peranan yang paling penting dalam implementasi ISO 9001:2015 adalah faktor komunikasi pelanggan.

4. Aktor yang memegang peranan paling penting dalam implementasi ISO 9001:2015 adalah top management.

5. Tujuan utama dari pengimplementasian ISO 9001:2015 adalah meningkatkan kompetensi pengadaan barang/jasa

6. Alternatif tindakan utama yang dapat dilakukan untuk mengatasi masalah yang timbul saat mengimplementasikan ISO 9001:2015 adalah pendidikan dan pelatihan.

\section{Saran}

Berdasarkan kesimpulan tersebut, berikut ini merupakan saran yang dapat dilakukan oleh Direktorat Pelatihan Kompetensi LKPP.

1. Direktorat Pelatihan Kompetensi LKPP diharapkan dapat mempertahankan dan senantiasa meningkatkan kualitas dan intensitas komunikasi dengan pelanggannya.

2. Direktorat Pelatihan Kompetensi LKPP diharapkan dapat senantiasa meningkatkan kompetensi pengadaan barang/jasa dan mutu pelayanan.

3. Direktorat Pelatihan Kompetensi LKPP diharapkan dapat meningkatkan kegiatan pendidikan dan pelatihan yang terjadwal bagi para pegawai untuk meningkatkan kompetensi dan pengetahuan para pegawai tersebut mengenai ISO agar para pegawai yang dimaksud dapat menerapkan sistem manajemen mutu dengan baik.

\section{DAFTAR PUSTAKA}

Assauri, S. 2008. Manajemen Produksi dan Operasi. Edisi Revisi 2008. Fakultas Ekonomi Universitas Indonesia. Jakarta.

Badan Standarisasi Nasional. 2015. Sistem Manajemen Mutu - Persyaratan SNI ISO 9001:2015. Badan Standarisasi Nasional. Jakarta.

Crocker, O.L., S. Charney dan J.S.L. Chiu. 2002. Quality Circles: A Guide to Participation and Productivity. $5^{\text {th }}$ Ed. Facts On File Publications. New York. Terjemahan Anas Sidik. 2010. Gugus Kendali Mutu: Pedoman, Partisipasi dan Produktivitas. Edisi 5. Bumi Aksara. Jakarta.

Crosby, P.B. 2002. Quality is Free: The Art of Making Quality Certain. $3^{\text {rd }}$ Edition. McGrawHill. New York. 
Gaspersz, V. 2002. Total Quality Management. $3^{\text {rd }}$ Edition. McGraw-Hill. New York. Terjemahan Z. Soeyoeti. 2013. Manajemen Mutu Terpadu. Edisi 3. Gramedia Pustaka Utama. Jakarta.

Goetsch, D.L. dan S.B. Davis. 2002. Introduction to Total Quality: Quality Management for Production, Process, and Service. $3^{\text {rd }}$ Ed. Prentice Hall. New Jersey. Terjemahan B. Molan. 2008. Pengantar Manajemen Mutu. Edisi 3. Prenhallindo. Jakarta.

Hadiwiardjo, B.H. dan W. Sulistijarningsih. 2008. Memasuki Pasar Internasional dengan ISO 9000: Sistem Manajemen Mutu. Ghalia Indonesia. Jakarta.

ISO. 2008. ISO 9001 - Quality Management. September. http://www.iso.org/. 24 September 2017 (08.45).

Lembaga Kebijakan Pengadaan Barang/Jasa Pemerintah. 2017. Direktorat Pelatihan Kompetensi Raih ISO 9001:2015. http://www.lkpp.go.id/\#/read/4728. 24 September 2017 (10:10).

Lloyd's Register Quality Assurance. 2017. Mutu Sebagai Standar. http://www.id.lrqa.com/quality/. 24 September 2017 (07:18).

Margono, S. 2010. Metode Penelitian Pendidikan. Rineka Cipta. Jakarta.

Marimin. 2008. Teknik dan Aplikasi Pengambilan Keputusan Kriteria Majemuk. Grasindo. Jakarta.

Nasution, M.N. 2015. Manajemen Mutu Terpadu. Ghalia Indonesia. Bogor.

Parasuraman, A., V.A. Zeithaml, dan L.L. Berry. 2008. Ressessment of Expectations as Comparison Standard in Measuring Service Quality: Implications for Further Research. International Journal of Marketing. 58(99): 111-142.

Peraturan Presiden Republik Indonesia Nomor 81 Tahun 2010. Grand Design Reformasi Birokrasi 2010-2025. 21 Desember 2010. Jakarta.

Prawirosentono, S. 2007. Riset Operasi dan Ekonofisika. Bumi Aksara. Jakarta.

Rakhmawati, T., S. Sumaedi dan N.J. Astrini. 2014. ISO 9001 in Health Service Sector: A Review and Future Research Proposal. International Journal of Quality and Service Sciences. 6(1): 17-29.

Rundle, J. 2015. Seven Principles of Quality Management as per ISO 9001:2015 Committee Draft. https://www.linkedin.com/pulse/seven-principles-quality-management-per-iso90012015-committee?trk=mp-reader-card. 21 November 2017 (15:45).

Sallis, E. 2006. Total Quality Management in Education. Terjemahan A.A. Riyadi dan Fahrurrozi. IRCiSoD. Yogyakarta. 
Sulaeman. 2014. Analisa Pengendalian Kualitas untuk Mengurangi Produk Cacat Speedometer Mobil dengan Menggunakan Metode QCC di PT INS. Jurnal PASTI. 8(1): 71-95.

Tampubolon, M. P. 2012. Manajemen Operasional. Ghalia Indonesia. Jakarta.

Tjiptono, F. dan A. Diana. 2008. Total Quality Management. Edisi Kelima. Andi Offset. Yogyakarta.

dan G. Chandra. 2008. Service Quality and Satisfaction. Andi Offset. Yogyakarta.

Undang-Undang Republik Indonesia Nomor 25 Tahun 2009. Pelayanan Publik. 18 Juli 2009. Lembaran Negara Republik Indonesia Tahun 2009 Nomor 112. Jakarta. 